\title{
Effect of Gamma Radiation on Some
} Morphological and Biochemical

\section{Characteristics of Brassica napus $\mathbf{L}$. (variety Bulbul 98)}

Wisal Muhammad Khan*1, Syed Zahir Shah ${ }^{1}$, Luqman Shah ${ }^{1}$, Muhammad Saleem Khan ${ }^{1}$, Zahir Muhammad ${ }^{2}$, Izhar Ahmad ${ }^{1}$, Maqsood Anwar ${ }^{1}$, Sajjad Ali ${ }^{3}$

${ }^{1}$ Department of Botany, Islamia College Peshawar, KPK, Pakistan.

${ }^{2}$ Department of Botany, University of Peshawar, KPK, Pakistan.

${ }^{3}$ Department of Botany, Bacha Khan University, Charsadda, KPK, Pakistan.

*Corresponding author email: wisalmadani@ hotmail.com

\section{Citation}

Wisal Muhammad Khan, Syed Zahir Shah, Luqman Shah, Muhammad Saleem Khan, Zahir Muhammad, Izhar Ahmad, Maqsood Anwar, Sajjad Ali. Effect of Gamma Radiation on Some Morphological and Biochemical Characteristics of Brassica napus L. (variety Bulbul 98). Pure and Applied Biology. Vol. 4, Issue 2, 2015, pp 236-243

Received: $26 / 03 / 2015$

Revised: 23/04/2015

Accepted: 04/05/2015

\section{Abstract}

The present work was aimed to study the effectiveness of different doses of Gamma radiations (5 $\mathrm{Krad}, 15 \mathrm{Krad}, 25 \mathrm{Krad}, 35 \mathrm{Krad}$ and $45 \mathrm{Krad}$ ) on days to germination, days to flowering, plant height, number of branches/plant, number of siliqua/plant, number of seeds/siliqua, siliqua length, 1000-seeds weight, oil, glucosinulates, moisture, proteins, oleic acid, linolenic acid and erucic acid contents. The results showed that Gamma radiation has no significant effect on days to germination and days to flowering. However, at $5 \mathrm{Krad}$ and $15 \mathrm{Krad}$ enhanced germination (5 days) as compared to control (7 days), while days to flowering were delayed (110 days) in higher dose (45 Krad) as compared to control (96 days). A significant decrease was noticed in plant height $(97.6 \mathrm{~cm})$ and number of siliqua/plant (101) compared to control $(101.8 \mathrm{~cm}$ and 150$)$. Higher dose (45 Krad) enhanced number of branches/plant (5), number of seeds/siliqua (27) and siliqua length $(5.14 \mathrm{~cm})$ as compared to control $(4,25$ and $4.7 \mathrm{~cm})$. On the other hand higher doses of radiation decreased oil contents $(49.2 \%)$, protein contents $(21.3 \%)$, oleic acid $(61.4 \%)$ and erucic acid (19.7\%) compared to control $(51.6 \%, 29.0 \%, 67.1 \%$ and $21.5 \%$ respectively). A considerable increase was noticed in glucosinulates $(16.1 \%)$, linolenic acid $(11.5 \%)$ and moisture (5.5\%) contents as compared to control (12.4\% and 9.5\% and (5.2\%) respectively.

Keyword: Brassica; Gamma radiation; Morphological Biochemical characteristics

\section{Introduction}

Canola (Brassica napus L.) belongs to the family Brassicaceae (Cruciferae). The name
Brassicaceae is derived from the included genus Brassica. This family contains 330 genera and about 3,700 species. The family 
contains important and well known species such as Brassica oleracea and Brassica rapa. Brassica napus is one of the most important oilseed crops throughout the world which rank third among the oilseed crops after soybean and oil palm in production of vegetables oil [1]. Commonly this crop is known as "Sarsoon". The most important types grown in Pakistan are Brassica compestris, Brassica juncea, and Brassica napus. Rape seed refers to Brassica compestris and Brassica napus. Due to the low concentration of erucic acid and glucosinulate contents Brassica compestris and Brassica napus have been preferred over other species of Brassica. The plant is also used to produce a high quality protein and extraction of oil, the residual high protein meal can be soaked in water and fed to cattle [2]. The name crucifer comes from the shape of flowers, with four diagonally opposite petals in the form of a cross. Brassica napus has dark bluish green foliage, glucose, smooth, or with a few scattered hairs near the margins and partially clasping. It is annual herb. Mature Brassica napus plants grow to the height of one to two meters. The stem is well branched, although the degree of branching depends on variety and environmental conditions. Branches originate in the axils of the highest leaves on the stem, and each terminates in an inflorescence. The lower leaves are deeply lobed, while the upper leaves are narrow and entire. Lower leaves petiolated, green and sometime with a whitish bloom. Ovate to obovat, variously lobed with toothed or frilled edges. The flowers are pale yellow and open progressively upward from the base of the raceme. The flowers are hermaphrodite. The plant is self-fertile. The seed pods are slightly apprised and 2.5 to 5 $\mathrm{cm}$ in length exclusive of the beak. The beak is 0.5 to $1 \mathrm{~cm}$ long. Seeds are round and brown or black. The plants prefer sandy, loamy and clay soils and require well drainage soil. The plant prefers acid, neutral and basic (alkaline) soils and can grow in very acid and very alkaline soils. Also can grow in semi shade or no shade.

It was less useful as food for animals or human because it has a bitter taste due to high levels of glucosinolates. Varieties have now been bred to reduce the content of glucosinolates, yielding more palatable oil. Nowadays Rapeseed is grown for the production of animal feed, vegetable oil for human consumption and biodiesel, leading producers include the European Union, Canada the United States, Australia, china and India. According to the United states Department of agriculture rapeseed was the third leading source of vegetable oil in the world in 2000, after soybean and oil palm. World production is growing rapidly, with FAO reporting 36 million tons of rapeseed was produced in the 2003-2004 season, and estimating 58.4 million tons in the 20102011 season.

Rapeseed and mustard is an important oilseed crop in Pakistan. It is grown over an area of 339.9 thousand hectare having an average yield of $85.9 \mathrm{~kg}$ per hectare. Pakistan has become world's third largest edible oil importer [3]. Edible oil consumption in Pakistan during 2008-09 was 2.821 million tons, where the local production stood at 0.68 million tons which accounted for $24 \%$ of total availability, while the remaining $76 \%$ was made available through imports. As the total demand for the year 2009-10 was 3.45 million tons, of which 0.855 million tons was locally produced from all sources and rest of the oil (2.550) was made available through imports costing 87 billion rupees [4]. In Pakistan during the year, 2010-11 total cultivated area under rapeseed was 439 thousand acres, producing 157 thousand tons of seed, which yielded 50 thousand tons of oil. While in 2011-12, the total cultivated area under rapeseed was 575 
thousand acres, producing 203 thousand tons of seed, which yielded 61 thousand tons of oil [5]. After cotton, rapeseed-mustard is the second most important source of domestic oil production. Oil from conventional rapeseed and mustard is not considered as regular cooking oil because of its inferior quality due to the presence of high erucic acid (more than 40\%) and glucosinolates (more than $100 \mu$ mole $/ g$ of dry meal) and low level of oleic and linoleic acids.

Mutation breeding is a supplementary breeding method which is rapid, potential and valuable tool to create genetic variability for various quantitative and qualitative characters in crop plants. In general mutation refers to sudden heritable change in the phenotype of an individual which may occur naturally or by artificial induction due to change in the Deoxyribonucleic Acid (DNA) sequences of a gene. Induced mutations are produced by the use of mutagenic agents like physical mutagens (x-rays, Gamma rays etc.) and chemical mutagens (alkaylating agents, base analogues etc.). However gamma rays act on genetic material by ionization leading to more of chromosomal rather than point mutations and gamma rays are successfully used in plant breeding program because of its simple application, good penetration, reproducibility and high mutation frequency and less disposal problems. Plants created using mutagenesis are sometime called mutagenic plants or mutagenic seeds. From 1930-2007 more than 2540 mutagenic plant varieties have been released that have been derived either as direct mutants (70 percent) or from their progeny (30 percent).Mutation breeding is commonly used to produce traits in crops such as larger seeds, new colors, sweet fruits etc that either cannot be found in nature or have been lost during evolution. Among the different breeding methods, induced mutation has been extensively and successfully used for genetic improvement of any yield attributes, either qualitative or quantitative in nature for rapeseed-mustard and other crops [6]. Induced mutations have been accepted as useful tool in a plant breeding program. One of the most important roles of mutation breeding is the genetic variability in quantitative traits in various crop plants. Mutagenesis provides a unique opportunity for the improvement of Brassica. Physical and chemical mutagens have been successfully used in rapeseed mustard to evolve new varieties with improved economic traits. Nuclear technology has been greatly utilized for the global benefit of mankind, not only in the field of medical science, but also in agriculture. Nuclear technology involving the use of ionizing radiation for mutation induction has been successfully applied worldwide in developing new varieties of crop plants [7]. Some mutations might be beneficial and have high economic value. Gamma rays generally influence plant growth and development by inducing cytological, genetically, biochemical, physiological and morphogenetic changes in cell and tissue. There are some reports which showed that the higher exposure of gamma rays were usually inhibitory, where lower exposure were sometimes stimulatory [8]. Literature shows that more than 2700 mutant varieties of different crops with improved agronomic traits have been developed and released to the farmers for general cultivation all over the world $[9,10]$. The present work aimed to investigate effect of different doses of gamma irradiation $(0,5,15,25,35,45 \mathrm{k}$ rad) on growth, yield and quality of Brassica napus L.

\section{Materials and Methods}

\section{Plant material and radiation treatment:}

In the present study Brassica napus L. variety "Bulbul 98" was used. Seeds were obtained from Institute of Biotechnology 
and Genetic Engineering (IBGE), The University of Agriculture Peshawar. The seeds were treated with different doses of gamma radiations i.e. 5, 15, 25, 35 and 45 Krad at Nuclear Institute for Food and Agriculture (NIFA) Peshawar, Pakistan via cobalt-60 radiation source.

\section{Field experiment}

The irradiated and control seeds were sown in the Botanical Garden, Department of Botany, Islamia College Peshawar, on 22 November 2013. Irradiated seeds of each dose were sown in 5 replica pots in green house. Various growth stages of plants from germination to harvest were noted timely.

\section{Parameters}

Various agronomic and morphological characters were measured during the plant's life span. It includes the following:

$\begin{array}{ll}> & \text { Days to germination } \\ > & \text { Days to flowering } \\ > & \text { Number of branches per plant } \\ > & \text { Number of siliqua per plant } \\ > & \text { Number of seeds per siliqua } \\ > & \text { Siliqua length }\end{array}$

\section{Results and Discussions}

Effect of gamma radiations on days to germination, days to flowering, plant height and number of branches/plant:

\section{Days to germination}

Table 1 show that gamma radiation has no significant effect on days to germination. However, the $5 \mathrm{Krad}$ and $15 \mathrm{Krad}$ doses show stimulatory effect on seed germination as compared to control and $25 \mathrm{Krad}, 35$ $\mathrm{Krad}$ and $45 \mathrm{Krad}$. Delay in germination may be due to inhibitory effects of gamma rays on seed dormancy. There was no significant difference in germination and survival percentage of irradiated and nonirradiated seedlings of Brassica napus [11].

\section{Days to flowering}

Table 1 shows the effect of gamma radiation on days to flowering. Gamma radiation has significant effects on days to flowering. Higher doses of gamma rays may delay the flowering. With increase of dose flowering also delay i.e. $5 \mathrm{Krad}$ (99 days), $15 \mathrm{Krad}$ (99 days) $25 \mathrm{Krad}$ (99 days), $35 \mathrm{Krad}$ (98 days) and $45 \mathrm{Krad}$ (110 days) as compared control (96 days). Emrani et al. [12] reported that mutagen treatment increase days to flowering.

\section{Plant height}

Table 1 represents the effect of gamma radiation on plant height. The result show decreasing tendency in the mean values of plant height with higher doses of radiation i.e. $15 \mathrm{Krad}(107 \mathrm{~cm}), 25 \mathrm{Krad}(97.6 \mathrm{~cm}), 35$ $\operatorname{Krad}(102.6 \mathrm{~cm})$ and $45 \operatorname{Krad}(101 \mathrm{~cm})$ except $5 \mathrm{Krad}(117.2 \mathrm{~cm})$ which is the highest value. In higher doses i.e. $25 \mathrm{Krad}$, $35 \mathrm{Krad}$ and $45 \mathrm{Krad}$ a significant decrease in plant height was noted $(97.6 \mathrm{~cm}, 102.6 \mathrm{~cm}$ and $101 \mathrm{~cm}$ ) respectively and short statured plants are produced. The reduction in plant height can be attributed to reduction in mitotic activity of meristematic tissue and reduced moisture content in seeds as reported by Khalil et al. [13].

\section{Number of branches/plant}

The data of Table 1 shows the effect of gamma radiation on number of branches/plant. The highest numbers of branches/plant were noticed in $35 \mathrm{Krad}$ (6 branches/plant) and in $15 \mathrm{Krad}$ (5 branches/plant). The lowest value for number of branches/plant was noticed in control, $25 \mathrm{Krad}$ and $45 \mathrm{Krad}$ which are (4.6 $\mathrm{cm})$. A reduction in plant height and number of branches for many crops that were exposed to higher gamma ray doses had already been reported by Muhammad and Afsari [14].

Effect of Gamma Radiations on number of siliqua/plant, number of seeds/siliqua, siliqua length, 1000 seeds weight:

Number of siliqua/plant

The data of Table 2 shows the results for number of siliqua/plant. The results show 
variation in the mean value for number of siliqua/plant. $5 \mathrm{Krad}, 35 \mathrm{Krad}$ and $45 \mathrm{Krad}$ doses have the highest mean value for number of branches/plant. Control and 15 Krad have the lowest mean value for number of Siliqua/plant. An increase is noticed in $45 \mathrm{Krad}$ (196.8 siliqua/plant) as compared to $15 \mathrm{Krad}$ (100.8 siliqua/plant) and other doses. Increased number of fruit/plant and seed/siliqua as a result of gamma irradiation was recorded by $[15,16]$.

\section{Number of seeds/siliqua}

Table 2 represents the effect of gamma radiation on number of seeds/siliqua. The results show variations in the mean value for number of seeds/siliqua. Control, $5 \mathrm{Krad}, 35$ $\mathrm{Krad}$ and $45 \mathrm{Krad}$ doses have highest mean value for number of seeds/siliqua. $15 \mathrm{Krad}$ and $25 \mathrm{Krad}$ have the lowest mean value for number of seeds/siliqua. An increase is noticed in $5 \mathrm{Krad}$ and $45 \mathrm{Krad}(26.8$ and 26.6 respectively) as compared to $25 \mathrm{Krad}$ and other doses.

\section{Siliqua length}

The data of Table 2 shows the effect gamma radiation on siliqua length. Length showed a varying tendency for various doses. $5 \mathrm{Krad}$, $15 \mathrm{Krad}$ and $45 \mathrm{Krad}$ have the highest value for siliqua length (4.82, 4.68 and 5.14 respectively). For control $15 \mathrm{Krad}$ the mean value for siliqua length were 4.7, 4.68 and $35 \mathrm{Krad}$ showed $4.62 \mathrm{~cm}$ which was the lowest value of all doses.

\section{0 seeds weight}

The data of Table 2 shows the effect of gamma radiation on 1000 seeds weight. A varying tendency was noted for 1000 seeds weight. The highest value was noted for $5 \mathrm{~K}$ rad dose (4.32 $\mathrm{g}$ respectively) while the lowest value was noted for $45 \mathrm{Krad}$ treatments (3.38 g respectively).The control, $15 \mathrm{Krad}, 25 \mathrm{Krad}$ and $35 \mathrm{Krad}$ doses were (3.77 g, $3.97 \mathrm{~g}$ and $3.81 \mathrm{~g}$ respectively). Higher irradiation doses affect 1000 Seeds weight negatively and decreases its means value for all doses except $35 \mathrm{Krad}$. The present results coincide with those.

\section{Biochemical Analysis of Seeds:}

\section{Oil percentage}

Seeds of Brassica napus were analyzed for oil contents and the data (Table 3 ) revealed that the oil contents decreased significantly with increasing radiation doses. The lowest oil contents $(49.2 \%)$ were recorded for $25 \mathrm{Kraddose}$, while the highest oil contents (51.6\%) were recorded for control. Increasing radiation decreases the oil content. The similar result was reported by [17].

\section{Protein percentage}

Seeds were analyzed for protein contents. The results showed that the Protein contents decrease with increasing radiation except 5 $\mathrm{Krad}$ and $35 \mathrm{Krad}$ which is $32.1 \%$ and 26.5 $\%$ respectively. The high amount of proteins were recorded in control (29\%) while the lowest proteins content were recorded in 15 $\mathrm{Krad}, 25 \mathrm{Krad}$ and $45 \mathrm{Krad}$ which is (22\%, $22.3 \%$ and $21.1 \%$ respectively). Our results are supported by previous published studies that decrease in protein production by gamma irradiation reported by [18-20].

\section{Glucosinulate contents}

Seeds were analyzed for glucosinulate (GSL) contents. The results showed that with increasing doses of gamma rays, the GSL contents were significantly increased, while an equality was noticed in $45 \mathrm{Krad}(12.8)$ which showed equal amount GSL contents like control. The result was investigated by Gharaghani et al. [21].

\section{Moisture}

Seeds were analyzed for moisture contents. The results showed that with increasing radiation doses the moisture contents of the seeds increased significantly as compared to control except $(5.0 \%)$ with the $5 \mathrm{Krad}$ which showed lower mean value for moisture compared to control. 
Table-1. Effect of gamma radiations on morphological and yield components of Brassica napus

\begin{tabular}{|c|c|c|c|c|c|c|c|c|}
\hline \multirow{2}{*}{ Doses } & \multicolumn{7}{|c|}{ PARAMETERS } \\
\cline { 2 - 9 } & $\begin{array}{c}\text { Days to } \\
\text { germination }\end{array}$ & $\begin{array}{c}\text { Days to } \\
\text { flowering }\end{array}$ & Plant height & $\begin{array}{c}\text { Number of } \\
\text { branches/plant }\end{array}$ & $\begin{array}{c}\text { Number of } \\
\text { siliqua/plant }\end{array}$ & $\begin{array}{c}\text { Number of } \\
\text { seeds/siliqua }\end{array}$ & $\begin{array}{c}\text { Siliqua } \\
\text { length }\end{array}$ & $\begin{array}{c}\text { 1000 seeds } \\
\text { weight }\end{array}$ \\
\hline Control & 7 & 96 & $101.8 \mathrm{~b}$ & $4.6 \mathrm{c}$ & $130.6 \mathrm{bc}$ & $25.8 \mathrm{a}$ & $4.7 \mathrm{~d}$ & 3.77 \\
\hline $\mathbf{5 ~ K r a d}$ & 5 & 99 & $117.2 \mathrm{a}$ & $4.8 \mathrm{bc}$ & $150.4 \mathrm{~b}$ & $26.8 \mathrm{a}$ & $4.82 \mathrm{~b}$ & 4.32 \\
\hline 15 Krad & 5 & 99 & $107 \mathrm{~b}$ & $5 \mathrm{~b}$ & $100.8 \mathrm{~d}$ & $23.6 \mathrm{~b}$ & $4.68 \mathrm{bc}$ & 3.97 \\
\hline $\mathbf{2 5} \mathbf{~ K r a d}$ & 7 & 99 & $97.6 \mathrm{c}$ & $4.6 \mathrm{c}$ & $114.4 \mathrm{bc}$ & $21.4 \mathrm{bc}$ & $4.62 \mathrm{c}$ & 3.67 \\
\hline 35 Krad & 7 & 98 & $102.6 \mathrm{~b}$ & $5.2 \mathrm{a}$ & $139.4 \mathrm{~b}$ & $25 \mathrm{a}$ & $4.6 \mathrm{~d}$ & 3.81 \\
\hline $\mathbf{4 5} \mathbf{K r a d}$ & 7 & 110 & $101 \mathrm{~b}$ & $4.6 \mathrm{c}$ & $196.8 \mathrm{a}$ & $26.6 \mathrm{a}$ & $5.14 \mathrm{a}$ & 3.38 \\
\hline
\end{tabular}

LSD at $0.05 \alpha$ level for plant height $=15.431$

LSD at $0.05 \alpha$ level for number of branches/plant $=1.266$

LSD at $0.05 \alpha$ level for number of siliqua/plant $=43.185$

LSD at $0.05 \alpha$ level for number of seeds/siliqua $=2.771$

LSD at $0.05 \alpha$ level for siliqua length $=0.06$

Table-2. Biochemical Analysis of Seeds. The quantitative analysis of seeds was carried out using NIRS (Near Infra Red Reflectance Spectroscopy) which works on the principle of measuring the absorption of light energy or wavelengths of each component at its characteristic frequency in the near IR region.

\begin{tabular}{|l|l|l|l|l|l|l|l|}
\hline Doses & Oil \% & Protein \% & $\begin{array}{l}\text { Glucosinulates } \\
\boldsymbol{\mu m o l} / \mathbf{g}\end{array}$ & Moisture \% & $\begin{array}{l}\text { Oleic Acid } \\
(\mathbf{1 8 : 0 1 ) \%}\end{array}$ & $\begin{array}{l}\text { Linolenic Acid } \\
(\mathbf{1 8 : 0 3 )} \%\end{array}$ & $\begin{array}{l}\text { Erucic Acid } \\
(\mathbf{2 2 : 0 1})\end{array}$ \\
\hline Control & 51.6 & 29.0 & 12.4 & 5.2 & 67.1 & 9.5 & 14.5 \\
\hline 5 Krad & 50.2 & 32.1 & 16.1 & 5.0 & 62.4 & 9.6 & 17.9 \\
\hline 15 Krad & 50.5 & 22.0 & 15.1 & 5.2 & 64.5 & 9.9 & 13.4 \\
\hline 25 Krad & 49.2 & 22.3 & 14.5 & 5.2 & 63.5 & 10.1 & 13.7 \\
\hline 35 Krad & 50.1 & 26.5 & 14.5 & 5.4 & 62.4 & 11.5 & 15.1 \\
\hline 45 Krad & 50.9 & 21.3 & 12.8 & 5.5 & 65.7 & 9.7 & 12.7 \\
\hline $\begin{array}{l}\text { C.V (Coefficient } \\
\text { Variation) }\end{array}$ & 5.23 & 17.24 & 9.83 & 3.35 & 3.29 & 7.38 & 8.55 \\
\hline
\end{tabular}

The values of the equilibrium moisture contents increased with increasing radiation dose. In contrast increasing gamma radiation moisture contents decreased significantly.

\section{Oleic acid (18:01)}

The collected seeds were analyzed for oleic acid content. The result (Table 3) revealed that the oleic acid contents significantly decreased with the increasing doses of gamma rays. Higher dose i.e. $25 \mathrm{Krad}$ showed in decrease (61.4\% respectively) as compared to control (67.1\%). Higher radiation doses decreased oil content in different degrees, the oleic acid and erucic acid contents showed a drastic variation [22].

\section{Linolenic acid (18:03)}

The analysis of collected seeds compared to control revealed that the linolenic acid contents changed variously compared to control. Control shows the lowest mean value $(9.5 \%)$, while $35 \mathrm{Krad}$ show the highest mean value $(11.5 \%)$. Higher radiation doses increased oil content in different degrees except $45 \mathrm{Krad}$ with (9.7 $\%)$ which is almost equal to control (9.5\%). Erusic acid (22:01)

As shown in Table 3 Erucic Acid contents decreased significantly in the irradiated seeds with increasing doses of gamma rays except $5 \mathrm{Krad}$ with $(17.9 \%)$. The highest mean value for Erucic acid (17.9 \%) was found in $5 \mathrm{Krad}$ and the lowest (12.7\%) was found in the highest radiation dose i.e., 45 Krad. Similar result was also reported by [23].

\section{Conclusion}

The present study showed that $5 \mathrm{Krad}$ and $15 \mathrm{Krad}$ doses were the best rate for increasing all traits. Higher doses of gamma irradiation decreased all traits in this study. There was no significant change in days to germination in Brassica napus crop. The reduced germination due to inhibitory effect of Gamma radiation. Higher doses of gamma rays may delay the flowering. With 
increase of dose flowering also delay. Control 96 days while $5 \mathrm{Krad}, 15 \mathrm{Krad}, 25$ Krad, $35 \mathrm{Krad}$ and $45 \mathrm{Krad}$ (99, 99, 99, 98 and 110 days). Gamma Radiation has significant effect on plant height. The result show decreasing tendency in the mean values of plant height. Gamma radiation has no significant effect on number of branches. A varying tendency was noted for number of siliqua/plant, number of seeds/siliqua, siliqua length and 1000 seeds weight. The consequences showed that the gamma radiation has significant effect on protein, oil, oleic acid and erucic acid contents. Increasing radiation, protein and oil, oleic acid and erucic acid contents were decreased significantly.

\section{Acknowledgement}

We are thankful to Department of Botany, Islamia College Peshawar for providing necessary research facilities and working environment and also to the NIFA, Turnab, Peshawar for chemical analysis of seeds.

\section{References}

1. Miri Y \& Bagheri (2013). Evaluation Planting Date on Agronomical Traits of Canola (Brassica napus L) International Research Journal of Applied and Basic Sciences. 4(3): 601-603.

2. Gatlin DM, Barrows FT, Brown P, Dabrowski K, Gaylord TG, Hardy RW \& Wurtele E (2007). Expanding the utilization of sustainable plant products in aqua feeds: a review. Aquaculture Research. 38(6): 551579.

3. Sattar A, Cheema MA, Wahid MA, Saleem MF, Ghaffari MA, Hussain S \& Arshad MS (2013). Effect of sowing time on seed yield and oil contents of canola varieties. J. Glob. Innov. Agric. Soc. Sci.vol 1(1): 1-4.

4. Cheema MA, Sattar A, Wahid MA, Saleem MF \& Sadiq S (2012). Growth yield and quality response of various canola cultivars under agro-ecological condition of Faisalabad. Pak.J. Agri. Sci., 49(1): 35-39.
5. Azam SM, Farhatullah AN, Shah S \& Iqbal S (2013). Correlation studies for some agronomic and quality traits in Brassica napus L. Sarhad J of Agric. 29(4): 547-550.

6. Barve YY, Gupta RK, Bhadauria SS, Thakre RP \& Pawar SE (2009). Induced mutations for development of $B$. juncea canola quality varieties suitable for Indian agro-climatic conditions In: Induced Plant Mutations in Genomics Era. Food and Agriculture Organization of the United States, pp. 373-375.

7. Sigurbjornsson B \& Lachance LE (1987). The IAEA and the green revolution, IAEA,Blletin, 29(3): 38-42.

8. Thapa CB (1999). Effect of acute exposure of gamma rays on seed germination of Pinuskesiya Gord .P. Wallachia and A.B. Jacks. Botanica Orientals journal of Plant Science, 2 13-17.

9. Maluszynski M, Nichterlein KL, Zanten V \& Ahloowalia BS (2000). Officially released mutant varieties. The FAO/IAEA Database. Mutt. Breed. Rev. No. 12, IAEA, Vienna, Austria, pp.1-84.

10. Shu QY (2009). A Summary of the International Symposium on Induced Mutations Plants. Induced Plant Mutations in the Genomics Era. Food and Agriculture Organization of the United Nations, Rome, pp. 13-14.

11. Kiong A, LingPick A, Grace Lai SH \& Harun AR (2008). Physiological responses of Orthosiphonstamineus plantlets to gamma irradiation. Am-Eurasian $J$. Sustain. Agric., 2(2):135-149.

12. Emrani SN, Arzani A, Saeidi G, Abtahi M, Banifatemeh M, Parsa MB \& Fotokian MH (2012).Evaluation of Induced Genetic Variability in Agronomic Traits by Gamma Irradiation in Canola (Brassica napus L.).Pakistan Journal of Botany.44 (4): 1281-1288. 
13. Khalil SJ, Rehman S, Afridi K \& Jan MT (1986). Damage induced by gamma irradiation in morphological and chemical characteristics of barley. Sarhad J of Agric. 2, 45-54.

14. Muhammad R \& Asfari S (2001). Quantitative variations induced by gamma irradiation and gibberellic acid in M1 generation of Check pea. Sarhad J. Agric., 17(3):367-372.

15. Khan WM, Shah SZ, Khan MS, Islam Z, Ali S, Irshd M \& Zahid M (2014). Effect of gamma radiations on some morphological and biochemical characteristics of Brassica napus L. (variety Altex). International Journal of Biosciences. 4(10):36-41.

16. Sharma B \& Mishra K (2007). Micro-mutations for fruit number, fruit length and fruit yield characters in gammairradiated generation of ANKUR-40 variety of okra. Abelmoschuses culentus L.) Monech .International Journal of Plant Sciences 2(2): 208-211.

17. Rahimi MM \& Bahrani A (2011). Effect of gamma irradiation on qualitative and quantitative characteristics of canola (Brassica napus L.). Middle-East Journal of Scientific Research, 8(2): 519-525.

18. Gaber MH (2005). Effect of $\gamma$-irradiation on molecular properties of bo-vine serum albumin. J. Biosci. Bioeng, 100: 203206.

19. Chamani M, Molaei M, Foroudy F, Janmohammadi H \& Raisali G (2009). The effect of autoclave processing and gamma irradiation on apparent ileal digestibility in broiler breeders of amino acids from Brassica meal. Afr. J. Agric. Res., 4: 592598.

20. Taghinejad M, Shawrang P, Rezapour A, Saeghi AA \& Ebrahimi SR (2009). Changes in anti-nutritional factors, ruminaldegra-dability and in vitro protein digest-ibility of gamma irradiated Brassi-ca meal. J. Animal Veter. Adv., 8: 1298-1304. 21. Gharaghani H, Zaghari M, Shahosseini G \& Moravaj H (2010). Effect of gamma irradiation on anti-nutritional factors and nutritional value of canola meal for Broiler Chickens. J. Anim. Sci.Vol. 21, No. 101479 $-1485$

22. Guangyaol C, Guo-huai1 W, Feng L, Ming-jian N \& Ji-ren1 W (2007). Effect of Gamma Irradiation on Agronomic Characters and Quality of Rapeseed (Brassica napus L.). Acta Agriculturae Boreali-Sinica.

23. Iftikhar A \& FarhatUllah (2013). Environmental and Induced Mutations Influences on Oil Content, Oleic Acid and Erucic Acid in Rapseed. Sarhad J. Agric. 29.2 . 